\title{
PENGARUH JENIS EKSPLAN DAN KOMBINASI ZAT PENGATUR TUMBUH (ZPT) TERHADAP INDUKSI KALUS Begonia bimaensis Undaharta \& Ardaka SECARA IN VITRO
}

\section{Effects of explant types and plant growth regulator (PGR) on in vitro callus induction of Begonia bimaensis Undaharta \& Ardaka}

Ema Hendriyani*, Tri Warseno, Ni Kadek Erosi Undaharta

Pusat Penelitian Konservasi Tumbuhan dan Kebun Raya - LIPI

Jl. Ir. H Juanda No.13, Bogor, Jawa Barat

*Email: emahendriyani@gmail.com

Diterima/Received: 10 Januari 2020; Disetujui/Accepted: 30 Maret 2020

\begin{abstract}
Begonia bimaensis Undaharta \& Ardaka is a potential ornamental plant, and currently known only from one population in Sumbawa. Propagation programs, both conventional and in vitro culture are necessary to ensure its conservation. The aim of this research is to observe the effects of explant types and plant growth regulator combination (2,4-D and kinetin) in inducing callus from B. bimaensis leaf in vitro. Callus induction was initiated from three parts of leaf explant, namely petiole, leaf base, and leaf lamina. The explants were planted on Murashige \& Skoog (MS) medium with addition of 2,4-D and kinetin. Concentrations of 2,4-D were 0, 0.5, and 1 ppm, while kinetin concentrations were 0,1 , and $2 \mathrm{ppm}$. Each treatment was replicated 10 times. Results showed that leaf base was the best explant used for callus induction. Medium $D_{1} K_{2}$ (MS $+1 \mathrm{ppm}$ kinetin) showed the fastest time for callus induction that was at 20 days after planting. The highest percentage of callus production (100\%) was found on $D_{1} K_{3}$ (MS + 2ppm kinetin); $D_{2} K_{2}$ (MS + 0.5ppm 2,4-D + 1 ppm kinetin); $D_{2} K_{3}(M S+0.5 p p m$ 2,4-D + 2ppm kinetin) and $D_{3} K_{2}$ (MS + 1ppm 2,4-D + 1ppm kinetin).
\end{abstract}

Keywords: 2,4-D, Begonia, callus, in vitro, kinetin

\section{Abstrak}

Begonia bimaensis Undaharta \& Ardaka merupakan tumbuhan berpotensi hias yang tergolong endemik, hingga saat ini diketahui dari satu populasi saja di Sumbawa. Oleh karena itu perlu dilakukan upaya perbanyakan untuk mencegah jenis ini dari kepunahan. Perbanyakan in vitro melalui induksi kalus memiliki keuntungan karena dapat menghasilkan bibit tanaman dalam jumlah banyak dalam waktu relatif singkat. Tujuan penelitian ini adalah untuk mengetahui pengaruh jenis eksplan dan kombinasi ZPT (2,4-D dan kinetin) dalam menginduksi kalus pada daun B. bimaensis secara in vitro. Induksi kalus $B$. bimaensis diinisiasi dari eksplan daun yang dibagi menjadi tiga bagian yaitu: tangkai daun, pangkal daun, dan helaian daun. Ketiga jenis eksplan ditanam pada media induksi kalus menggunakan media dasar Murashige \& Skoog (MS) dengan penambahan zat pengatur tumbuh (ZPT) 2,4-D dan kinetin. Konsentrasi 2,4-D yang digunakan adalah 0, 0,5, dan 1 ppm. Sedangkan konsentrasi kinetin sebesar 0, 1, dan 2 ppm. Setiap perlakuan diulang sebanyak 10 kali. Hasil penelitian menunjukkan bahwa eksplan pangkal daun paling baik dalam menginduksi kalus. Kombinasi media yang paling cepat dalam menginduksi kalus pada $20 \mathrm{HST}$ adalah $\mathrm{D}_{1} \mathrm{~K}_{2}$ (MS + 1ppm kinetin). Sedangkan kombinasi media yang paling tinggi dalam menghasilkan persentase eksplan berkalus yaitu: $D_{1} K_{3}$ (MS + 2ppm kinetin); $D_{2} K_{2}$ (MS + 0.5ppm 2,4-D + 1 ppm kinetin); $D_{2} K_{3}(M S$ + 0.5ppm 2,4-D + 2ppm kinetin) dan $\mathrm{D}_{3} \mathrm{~K}_{2}$ (MS + 1ppm 2,4-D + 1ppm kinetin) sebesar 100\%.

Kata kunci: 2,4-D Begonia, in vitro, kalus, kinetin 


\section{PENDAHULUAN}

Begonia merupakan salah satu marga terbesar tanaman berbunga dan termasuk dalam suku Begoniaceae. Marga ini terdiri atas 1.924 jenis berstatus accepted species (Hughes et al. 2015). Jumlah ini diperkirakan akan terus bertambah hingga sekitar 2000-2500 jenis (Tian et al. 2018).

Begonia dapat diperbanyak secara vegetatif (stek batang dan daun) maupun generatif (biji), melalui metode konvensional maupun kultur jaringan. Rout et al. (2006) menyebutkan bahwa kultur jaringan telah digunakan secara luas dalam industri florikultur untuk perbanyakan berbagai komoditi tanaman hias, antara lain Begonia, mawar, krisan, dan Anthurium. Perbanyakan Begonia (jenis alam dan silangan) menggunakan teknik kultur jaringan telah banyak dilakukan, antara lain pada: B. elatior cv. Toran orange (Mendi et al. 2009); Begonia $\mathrm{x}$ hiemalis Fotsch. cv. Schwabenland Red (Awal 2009); B. parvula H. Lév. \& Vaniot (Hu et al. 2010); B. tuberous (Nhut et al. 2010); Begonia x tuberhybrida Voss (Nada et al. 2011); B. rex Putz. (Sara et al. 2012); B. rubrovenia var. meisneri C.B. Clarke (Kumaria et al. 2012); B. masoniana Irmsch. ex Ziesenh., B. rex 'Inca Fire', $B$. rex 'Fairy' (Manuela \& Carmen 2013); B. pavonina Ridl. (Rosilah et al. 2014); B. rex Putz. (Kaviani et al. 2015); B. homonyma Steud. (Kumari et al. 2017); dan B. salaziensis (Gaudich.) Warb. (Warseno et al. 2018).

Marga Begonia secara umum memiliki ciriciri seperti bentuk daun asimetris, sendi batang berdaging, warna dan bentuk bunga mencolok, sehingga menjadikan kelompok tanaman hias ini sangat mudah dikenali (Tebbit 2005). Jenis Begonia alam (wild type) biasanya memiliki daun dan bunga yang sederhana dengan bentuk tidak terlalu atraktif. Namun, ada beberapa jenis Begonia alam memiliki ciri khas unik dan menarik seperti pada bentuk daunnya ataupun perawakan tanamannya yang tinggi, sehingga karakter-karakter tersebut berpotensi untuk dikembangkan sebagai tanaman hias. Jenis-jenis Begonia alam dengan karakter unik tersebut dimiliki antara lain oleh $B$. brevirimosa Irmsch., B. droopiae Ardi, B. holocericeoides Ardi \& D.C. Thomas, dan B. puspitae Ardi. Begonia tersebut dapat digunakan sebagai sumber genetik untuk pengembangan varietas tanaman hias baru melalui proses persilangan (Siregar 2017).

Begonia bimaensis Undaharta \& Ardaka merupakan Begonia jenis baru yang ditemukan di Gunung Muria di Kabupaten Bima, Pulau Sumbawa, Indonesia, dan dideskripsikan pada tahun 2015. Jenis ini merupakan jenis endemik yang saat ini diketahui hanya dari satu populasi saja. $B$. bimaensis dicirikan dengan mempunyai rambut panjang putih, lebat pada permukaan atas daun. Bunga betina dengan empat tepal yang berbentuk sayap, ovarium berbentuk segitiga (Undaharta et al. 2015).

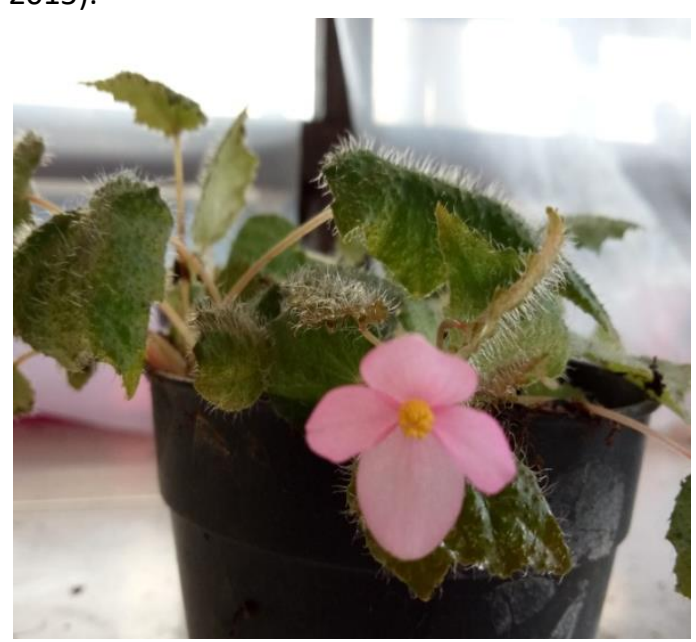

Gambar 1. Bunga Begonia bimaensis Undaharta \& Ardaka

Regenerasi tanaman melalui teknik kultur in vitro dapat berasal dari primordial organ pada ujung tunas dan tunas aksiler. Alternatif lainnya, tanaman dapat diregenerasi melalui jaringan kalus yang diperoleh dari eksplan yang diinduksi menggunakan zat pengatur tumbuh. Kalus adalah kumpulan sel yang tidak terorganisasi dan aktif membelah diri, sering terjadi karena perlukaan atau proses kultur pada jaringan tanaman (George 2008). Regenerasi tanaman dari kalus dimungkinkan oleh proses de novo organogenesis maupun embriogenesis somatik. Beberapa kelebihan kultur kalus antara lain, memudahkan dalam amplifikasi pembatasan bahan tanam serta dapat dihasilkan isolasi varian somaklonal langka. Rangsangan lingkungan, termasuk faktor zat pengatur tumbuh yang ditambahkan dalam sel kultur dapat memicu terbentuknya kalus pada eksplan yang ditanam.

Kalus dapat diperbanyak secara tidak terbatas dengan cara memindahkan sebagian kecil kalus kedalam medium baru (sub-kultur). Kalus 
dengan sel-sel yang bersifat meristematik, juga dapat didispersikan dalam medium cair sehingga diperoleh kultur suspensi sel. Teknik kultur jaringan melalui kultur kalus merupakan salah satu metode dalam budidaya tanaman hias untuk mendapatkan bibit tanaman yang seragam dan banyak, dalam waktu yang relatif singkat. Inisiasi induksi kalus atau disebut induksi kalus (Pierik 1987) dapat disebabkan karena adanya luka atau irisan pada eksplan, sebagai respon terhadap zat pengatur tumbuh, baik secara eksogen maupun endogen (Rosyidah et al. 2014).

Kombinasi zat pengatur tumbuh yang telah digunakan untuk induksi kalus pada berbagai jenis tanaman hias antara lain, naphthalene acetic acid (NAA) dan thidiazuron (TDZ) pada Phalaenopsis gigantea J.J.Sm. (Niknejad et al. 2011), NAA dan 2,4dichlorophenoxyacetic acid (2,4-D) pada Dendrobium sonia-28 (Mei et al. 2012), benzyl adenine (BA) dan 2,4-D pada Lilium leucantum (Baker) Baker (Tang et al. 2010), dan NAA dan BA pada Begonia homonyma Steud (Kumari et al. 2017).

Kombinasi zat pengatur tumbuh 2,4-D dan kinetin untuk induksi kalus telah banyak digunakan secara in vitro, antara lain pada Acalypha indica L. (Rahayu et al. 2003), Anthocephalus cadamba Miq. ex Roxb. (Kartikasari et al. 2013), dan Barringtonia racemosa (L.) Spreng. (Zawawi et al. 2013). Oleh karena itu, tujuan dari penelitian ini adalah untuk mengetahui pengaruh jenis eksplan dan kombinasi ZPT 2,4-D serta kinetin dalam menginduksi kalus pada jenis $B$. bimaensis secara in vitro.

\section{BAHAN DAN METODE}

\section{Lokasi dan waktu}

Penelitian ini dilaksanakan di laboratorium Kultur Jaringan Balai Konservasi Tumbuhan Kebun Raya Eka Karya Bali-LIPI pada bulan JanuariDesember 2018.

\section{Media}

Media dasar yang digunakan dalam penelitian ini adalah media Murashige \& Skoog (MS) (Murashige \& Skoog 1962). Pembuatan media dimulai dengan pembuatan larutan stok yaitu berupa makronutrien dan mikronutrien media MS, vitamin, dan ZPT. Larutan stok ZPT dibuat dengan menimbang 2,4-D) maupun kinetin sebanyak $10 \mathrm{mg}$, kemudian diberi beberapa tetes $\mathrm{NaOH} 1 \mathrm{~N}$ hingga larut sempurna dan ditambahkan aquades hingga volume larutan $100 \mathrm{ml}$

Larutan media dasar (media MS) ditambahkan glukosa sebanyak $20 \mathrm{~g} / \mathrm{l}$, kemudian diberi ZPT sesuai dengan kombinasi dan taraf konsentrasi perlakuan yaitu 2,4-D $(0,0,5$, dan 1 ppm) dan kinetin (0, 1, dan 2 ppm) untuk induksi kalus. Kertas $\mathrm{pH}$ meter digunakan untuk mengukur tingkat keasaman media. Pengaturan tingkat keasaman media dilakukan dengan penambahan $\mathrm{HCl}$ atau $\mathrm{NaOH}$ sehingga $\mathrm{pH}$ media 5,6-5,8. Setelah $\mathrm{pH}$ larutan sesuai, larutan media ditambahkan dengan 3,5 g/l gelrite sebagai zat pemadat. Media tersebut kemudian dipanaskan hingga mendidih dan diaduk sampai homogen. Selanjutnya media dituang dalam botol kultur sebanyak $20 \mathrm{ml} /$ botol. Botol berisi media ditutup rapat kemudian dimasukkan ke dalam autoklaf dengan suhu $121^{\circ} \mathrm{C}$ selama 20 menit. Setelah selesai, media disimpan dalam ruang penyimpanan media.

\section{Bahan tanaman dan sterilisasi eksplan}

Eksplan yang digunakan dalam penelitian ini adalah daun $B$. bimaensis yang ditanam di rumah kaca Begonia Kebun Raya Eka Karya Bali. Eksplan dicuci dengan deterjen dan dibilas pada air mengalir selama 15 menit untuk menghilangkan kotoran yang melekat pada permukaan daun. Kemudian eksplan disterilisasi dengan larutan alkohol 70\% selama 1 menit, dilanjutkan dengan larutan $\mathrm{NaClO}$ $5 \%$ yang ditambahkan tiga tetes Tween-20 selama 15 menit. Selanjutnya eksplan dibilas dengan akuades steril sebanyak tiga kali. Lalu eksplan daun dipotong menjadi tiga bagian yaitu tangkai daun, pangkal daun, dan helaian daun dengan ukuran 1 $\mathrm{cm}$. Eksplan tersebut kemudian ditanam di media perlakuan induksi kalus.

\section{Rancangan percobaan}

Penelitian dilakukan menggunakan rancangan percobaan faktorial lengkap $9 \times 3$ yang disusun dalam rancangan acak lengkap dengan 10 ulangan. Tabel 1 menunjukkan rancangan percobaan untuk mengetahui pengaruh jenis eksplan dan kombinasi konsentrasi ZPT 2,4-D dan kinetin yang digunakan untuk induksi kalus pada eksplan daun B. bimaensis. Masing-masing perlakukan terdiri atas 10 ulangan dengan 10 eksplan pada setiap ulangannya. Parameter yang 
diamati pada penelitian ini adalah waktu tumbuh kalus (hari setelah tanam/HST) dan persentase induksi kalus (\%).

Kultur dipelihara pada rak kultur dalam ruang inkubasi dengan pencahayaan lampu TLD 18 watt selama 12 jam dalam sehari, suhu ruangan 20$25^{\circ} \mathrm{C}$.

Tabel 1. Kombinasi perlakuan jenis eksplan dan konsentrasi ZPT untuk induksi kalus pada daun $B$. bimaensis

\begin{tabular}{lrlll}
\hline Jenis Eksplan & Kinetin & O ppm & 1 ppm & 2 ppm \\
\hline \multirow{2}{*}{ Tangkai Daun } & $\mathbf{0 ~ p p m}$ & $\mathrm{D}_{1} \mathrm{~K}_{1}$ & $\mathrm{D}_{1} \mathrm{~K}_{2}$ & $\mathrm{D}_{1} \mathrm{~K}_{3}$ \\
& $\mathbf{0 . 5} \mathbf{p p m}$ & $\mathrm{D}_{2} \mathrm{~K}_{1}$ & $\mathrm{D}_{2} \mathrm{~K}_{2}$ & $\mathrm{D}_{2} \mathrm{~K}_{3}$ \\
& $\mathbf{1} \mathbf{p p m}$ & $\mathrm{D}_{3} \mathrm{~K}_{1}$ & $\mathrm{D}_{3} \mathrm{~K}_{2}$ & $\mathrm{D}_{3} \mathrm{~K}_{3}$ \\
\hline \multirow{2}{*}{ Pangkal Daun } & $\mathbf{0 ~ p p m}$ & $\mathrm{D}_{1} \mathrm{~K}_{1}$ & $\mathrm{D}_{1} \mathrm{~K}_{2}$ & $\mathrm{D}_{1} \mathrm{~K}_{3}$ \\
& $\mathbf{0 . 5} \mathbf{p p m}$ & $\mathrm{D}_{2} \mathrm{~K}_{1}$ & $\mathrm{D}_{2} \mathrm{~K}_{2}$ & $\mathrm{D}_{2} \mathrm{~K}_{3}$ \\
& $\mathbf{1} \mathbf{p p m}$ & $\mathrm{D}_{3} \mathrm{~K}_{1}$ & $\mathrm{D}_{3} \mathrm{~K}_{2}$ & $\mathrm{D}_{3} \mathrm{~K}_{3}$ \\
\hline \multirow{2}{*}{ Helaian Daun } & $\mathbf{0 ~ p p m}$ & $\mathrm{D}_{1} \mathrm{~K}_{1}$ & $\mathrm{D}_{1} \mathrm{~K}_{2}$ & $\mathrm{D}_{1} \mathrm{~K}_{3}$ \\
& $\mathbf{0 . 5} \mathbf{p p m}$ & $\mathrm{D}_{2} \mathrm{~K}_{1}$ & $\mathrm{D}_{2} \mathrm{~K}_{2}$ & $\mathrm{D}_{2} \mathrm{~K}_{3}$ \\
& $\mathbf{1} \mathbf{p p m}$ & $\mathrm{D}_{3} \mathrm{~K}_{1}$ & $\mathrm{D}_{3} \mathrm{~K}_{2}$ & $\mathrm{D}_{3} \mathrm{~K}_{3}$ \\
\hline
\end{tabular}

\section{Analisis data}

Data yang dikumpulkan dalam penelitian ini berupa data kualitatif dan kuantitatif. Parameter pada data kualitatif meliputi morfologi dan warna kalus yang dianalisis secara deskriptif. Sedangkan parameter untuk data kuantitatif adalah waktu tumbuh kalus dan persentase induksi kalus yang diamati sejak dua minggu setelah tanam. Persentase induksi kalus dihitung berdasarkan rumus:

Persentase induksi kalus (CI \%)

$=\frac{\text { Jumlah eksplan yang berkalus }}{\text { Total jumlah eksplan }} \times 100 \%$

Data kuantitatif yang diperoleh kemudian dianalisis secara sidik ragam (ANOVA) dan uji rentang berganda Duncan $(P<0,05)$ digunakan untuk menentukan perbedaan signifikan antara rata-rata parameter yang dicatat. Analisis data dilakukan menggunakan program PROC ANOVA SAS Versi 9.1.

\section{HASIL DAN PEMBAHASAN}

Dari ketiga jenis eksplan yang digunakan, eksplan tangkai dan pangkal daun memberikan respon terhadap perlakuan induksi kalus. Pengaruh kombinasi ZPT 2,4-D dan kinetin terhadap eksplan daun B. bimaensis dapat dilihat pada Tabel 2. Kalus berhasil terbentuk di semua media yang diberikan ZPT kinetin (1 dan 2 ppm) baik pemberian tunggal maupun yang dikombinasikan dengan 2,4-D pada eksplan tangkai dan pangkal daun. Berdasarkan parameter persentase induksi kalus, pada eksplan pangkal daun, kalus yang terbentuk pada kombinasi media $D_{1} K_{3}, D_{2} K_{2}, D_{2} K_{3}, D_{3} K_{2}$ memberikan hasil paling baik (100\%). Pengamatan secara kualitatif juga menunjukkan bahwa pada kombinasi media tersebut, dihasilkan pertumbuhan kalus paling banyak dengan bentuk kalus kompak. Sedangkan pada parameter waktu berkalus paling cepat, kombinasi media $\mathrm{D}_{1} \mathrm{~K}_{2}$ memberikan hasil paling baik (20,3 HST) dari eksplan pangkal daun. Menurut Taiz \& Zeiger (2002), pada bagian pangkal daun terdapat zona absisi. Zona tersebut memiliki dinding sel lebih tipis dibandingkan sel di bagian helaian daun maupun tangkai daun. Oleh karena itu, sel-sel di pangkal daun lebih responsif dalam penyerapan nutrisi dan ZPT dari media induksi kalus, sehingga kalus lebih mudah terbentuk pada bagian pangkal daun dibandingkan bagian lainnya. Hal ini sejalan dengan penelitian yang dilakukan oleh Rowe \& Gallone (2016), bahwa eksplan pangkal daun pada B. rex 'Fedor' menghasilkan berat kalus tertinggi. Uji Anova yang dilanjutkan dengan uji Duncan menunjukkan adanya perbedaan pengaruh antara jenis eksplan terhadap induksi kalus pada kedua parameter kuantitatif yang diamati (Tabel 2). 
Tabel 2. Pengaruh jenis eksplan dan kombinasi ZPT 2,4-D dan kinetin terhadap pembentukan kalus pada daun $B$. bimaensis

\begin{tabular}{|c|c|c|c|c|c|}
\hline Jenis eksplan & Media & $\begin{array}{l}\text { Waktu tumbuh } \\
\text { kalus (HST) }\end{array}$ & $\begin{array}{l}\text { Persentase induksi } \\
\text { kalus (\%) }\end{array}$ & $\begin{array}{l}\text { Pertumbuhan } \\
\text { kalus }\end{array}$ & $\begin{array}{l}\text { Penampakan } \\
\text { pertumbuhan } \\
\text { kalus }\end{array}$ \\
\hline Tangkai daun & $\begin{array}{l}\mathrm{D}_{1} \mathrm{~K}_{1} \\
\mathrm{D}_{1} \mathrm{~K}_{2} \\
\mathrm{D}_{1} \mathrm{~K}_{3} \\
\mathrm{D}_{2} \mathrm{~K}_{1} \\
\mathrm{D}_{2} \mathrm{~K}_{2} \\
\mathrm{D}_{2} \mathrm{~K}_{3} \\
\mathrm{D}_{3} \mathrm{~K}_{1} \\
\mathrm{D}_{3} \mathrm{~K}_{2} \\
\mathrm{D}_{3} \mathrm{~K}_{3}\end{array}$ & $\begin{array}{c}0.0 \pm 0.00^{f} \\
24.5 \pm 9.47^{d} \\
37.1 \pm 3.38^{a} \\
0.00 \pm 0.00^{f} \\
30.1 \pm 3.38^{b} \\
37.1 \pm 3.38^{a} \\
0.00 \pm 0.00^{f} \\
29.4 \pm 5.52^{b c} \\
28.7 \pm 2.21^{b c}\end{array}$ & $\begin{array}{r}0.00 \pm 0.00^{f} \\
83.00 \pm 9.48^{d} \\
94.00 \pm 8.43^{b} \\
0.00 \pm 0.00^{f} \\
100.00 \pm 0.00^{a} \\
100.00 \pm 0.00^{a} \\
0.00 \pm 0.00^{f} \\
92.00 \pm 7.88^{b} \\
72.00 \pm 10.32^{\mathrm{e}}\end{array}$ & $\begin{array}{l}- \\
++ \\
++ \\
- \\
+++ \\
++ \\
- \\
+++ \\
++\end{array}$ & $\begin{array}{l}- \\
- \\
- \\
- \\
\text { Kompak } \\
\text { Kompak } \\
\text { Kompak } \\
\text { Kompak }\end{array}$ \\
\hline Pangkal daun & $\begin{array}{l}\mathrm{D}_{1} \mathrm{~K}_{1} \\
\mathrm{D}_{1} \mathrm{~K}_{2} \\
\mathrm{D}_{1} \mathrm{~K}_{3} \\
\mathrm{D}_{2} \mathrm{~K}_{1} \\
\mathrm{D}_{2} \mathrm{~K}_{2} \\
\mathrm{D}_{2} \mathrm{~K}_{3} \\
\mathrm{D}_{3} \mathrm{~K}_{1} \\
\mathrm{D}_{3} \mathrm{~K}_{2} \\
\mathrm{D}_{3} \mathrm{~K}_{3}\end{array}$ & $\begin{array}{l}0.00 \pm 0.00^{f} \\
20.3 \pm 10.14^{\mathrm{e}} \\
37.1 \pm 3.38^{\mathrm{a}} \\
0.00 \pm 0.00^{f} \\
28.7 \pm 2.21^{\mathrm{bc}} \\
36.4 \pm 2.95^{\mathrm{a}} \\
0.00 \pm 0.00^{f} \\
23.8 \pm 3.61^{d} \\
26.6 \pm 4.42^{c d}\end{array}$ & $\begin{array}{r}0.00 \pm 0.00^{f} \\
88.00 \pm 10.32^{\mathrm{c}} \\
100.00 \pm 0.00^{\mathrm{a}} \\
0.00 \pm 0.00^{\mathrm{f}} \\
100.00 \pm 0.00^{\mathrm{a}} \\
100.00 \pm 0.00^{\mathrm{a}} \\
0.00 \pm 0.00^{\mathrm{f}} \\
100.00 \pm 0.00^{\mathrm{a}} \\
74.00 \pm 10.74^{\mathrm{e}}\end{array}$ & $\begin{array}{l}- \\
++ \\
+++ \\
- \\
+++ \\
+++ \\
- \\
+++ \\
++\end{array}$ & $\begin{array}{l}\text { Kompak } \\
\text { Kompak } \\
\text { - } \\
\text { Kompak } \\
\text { Kompak } \\
\text { - } \\
\text { Kompak } \\
\text { Kompak }\end{array}$ \\
\hline Helaian daun & $\begin{array}{l}\mathrm{D}_{1} \mathrm{~K}_{1} \\
\mathrm{D}_{1} \mathrm{~K}_{2} \\
\mathrm{D}_{1} \mathrm{~K}_{3} \\
\mathrm{D}_{2} \mathrm{~K}_{1} \\
\mathrm{D}_{2} \mathrm{~K}_{2} \\
\mathrm{D}_{2} \mathrm{~K}_{3} \\
\mathrm{D}_{3} \mathrm{~K}_{1} \\
\mathrm{D}_{3} \mathrm{~K}_{2} \\
\mathrm{D}_{3} \mathrm{~K}_{3}\end{array}$ & $\begin{array}{l}0.00 \pm 0.00^{f} \\
0.00 \pm 0.00^{f} \\
0.00 \pm 0.00^{f} \\
0.00 \pm 0.00^{f} \\
0.00 \pm 0.00^{f} \\
0.00 \pm 0.00^{f} \\
0.00 \pm 0.00^{f} \\
0.00 \pm 0.00^{f} \\
0.00 \pm 0.00^{f}\end{array}$ & $\begin{array}{l}0.00 \pm 0.00^{f} \\
0.00 \pm 0.00^{f} \\
0.00 \pm 0.00^{f} \\
0.00 \pm 0.00^{f} \\
0.00 \pm 0.00^{f} \\
0.00 \pm 0.00^{f} \\
0.00 \pm 0.00^{f} \\
0.00 \pm 0.00^{f} \\
0.00 \pm 0.00^{f}\end{array}$ & $\begin{array}{l}- \\
- \\
- \\
- \\
- \\
- \\
- \\
- \\
-\end{array}$ & $\begin{array}{l}- \\
- \\
- \\
- \\
- \\
- \\
- \\
-\end{array}$ \\
\hline
\end{tabular}

Dalam penginduksian kalus diperlukan ZPT yang dikombinasikan dengan media dasar. Gunawan (1995) menyebutkan bahwa interaksi dan perimbangan antara ZPT yang ditambahkan ke dalam medium, dan yang diproduksi oleh sel secara endogen, dapat menentukan arah perkembangan suatu kultur. Penambahan ZPT pada medium dapat mengubah nisbah ZPT endogen, hal ini kemudian menjadi faktor penentu untuk proses pertumbuhan dan morfogenesis eksplan. Pada B. bimaensis ZPT 2,4-D dan kinetin berperan sebagai inisiator induksi kalus dan keduanya bekerja sinergis. Hal tersebut sejalan dengan pendapat Machakova et al. (2008) yang menyebutkan bahwa ZPT 2,4-D merupakan kelompok auksin. Pada tingkat seluler auksin berperan penting dalam pembelahan dan pemanjangan sel, sedangkan kinetin merupakan kelompok sitokinin yang berperan dalam merangsang pembelahan sel dan dapat meningkatkan pertumbuhan kalus (Van Staden et al. 2008). Hal ini dapat dilihat pada tabel 2 bahwa media perlakuan tanpa penambahan kinetin tidak menunjukkan respon terhadap induksi kalus.

Seiring dengan meningkatnya konsentrasi 2,4-D, maka persentase pembentukan kalus cenderung meningkat. Awal (2009) menyebutkan bahwa 2,4-D merupakan ZPT terbaik untuk menginduksi kalus. Hal ini didukung dengan banyaknya laporan penggunaan 2,4-D untuk induksi kalus pada beberapa jenis tanaman, antara lain Mirabilis jalapa L. (Ling et al. 2009); Triticum aestivum L. (Rashid et al. 2009); Lilium leucanthum (Baker) Baker (Tang et al. 2010); Saccharum officinarum L. (Tahir et al. 2011); Begonia x hiemalis 
Fotsch (Awal et al. 2013); Taxus brevifolia Nutt. (Karimian et al. 2014); Hordem vulgare L. (Abumhadi et al. 2014); Begonia pavonina Ridl. (Rosilah et al. 2014); serta Vanda sp. (Budisantoso et al. 2017).

Machakova et al. (2008) menyatakan bahwa pemberian 2,4-D pada konsentrasi rendah $(<2,5$ ppm), akan menunjukkan peningkatan respon seiring dengan peningkatan konsentrasinya. Tetapi pemberian 2,4-D di atas 2,5 ppm akan memberikan efek penghambatan. Respon yang sama juga terlihat pada B. malabarica dan B. rex-cultorum (Aswathy et al. 2017). Pada penelitian ini belum diketahui berapa konsentrasi 2,4-D yang bersifat menghambat pembentukan kalus pada $B$. bimaensis.

Selain faktor zat pengatur tumbuh endogen maupun eksogen, kalus dapat terbentuk saat sel mengalami kerusakan akibat perlukaan (Taiz \& Zeiger 2002), sehingga menyebabkan autolisis (pecahnya sel) dan sel memproduksi senyawa tertentu yang merangsang pembelahan sel di lapisan sel sebelahnya. Awal pertumbuhan kalus pada eksplan $B$. bimaensis ditandai dengan pembengkakan eksplan dan diikuti dengan munculnya kalus berwarna putih di ujung dan tepi eksplan tempat terjadinya perlukaan (Gambar 2 dan 3).
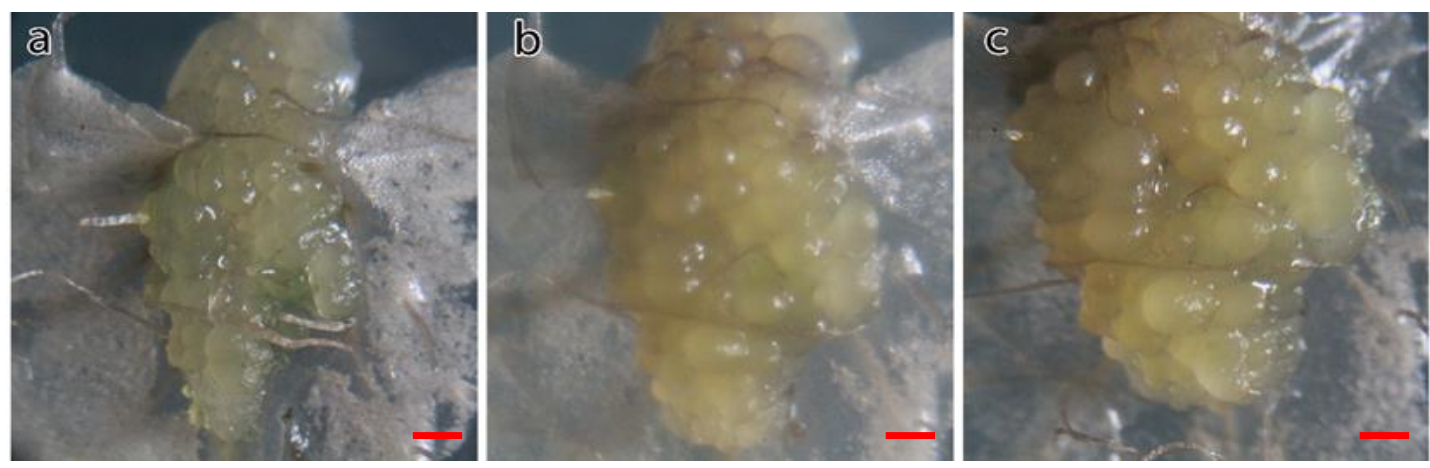

Gambar 2. Perkembangan kalus dari pangkal daun B. bimaensis pada media perlakuan: a. Umur 21 HST; b. Umur 28 HST; c. Umur 35 HST.

Pengamatan dilakukan dengan mikroskop stereo perbesaran 10x. Bar $=1 \mathrm{~mm}$
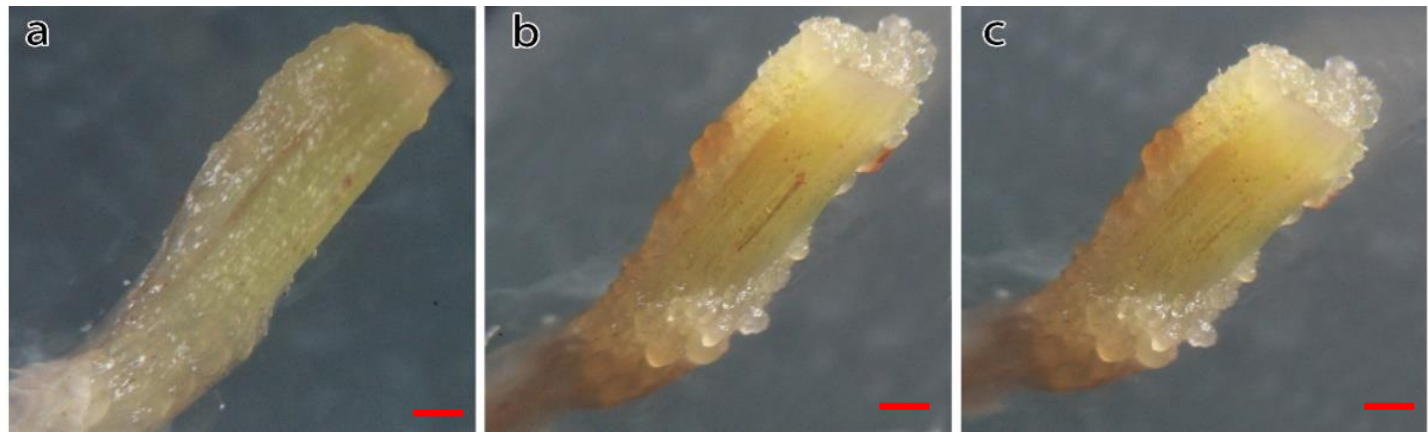

Gambar 3. Perkembangan kalus tangkai daun B. bimaensis pada media perlakuan:

a. Umur 21 HST; b. Umur 28 HST; c. Umur 35 HST.

Pengamatan dilakukan dengan mikroskop stereo perbesaran 10x. Bar=1mm

Tekstur kalus dapat bervariasi dari kompak hingga meremah tergantung pada jenis tanaman yang digunakan, komposisi media, zat pengatur tumbuh, dan kondisi lingkungan kultur (Pierik 1987). Kalus yang tumbuh pada eksplan daun $B$. bimaensis memiliki tekstur kompak dan berwarna putih kekuningan. Tekstur kalus kompak merupakan tekstur kalus yang padat, tidak mudah lepas atau hancur dan memiliki potensi untuk tumbuh atau berkembang menjadi organ melalui proses organogenesis, misalnya pembentukan akar atau tunas. Oleh karena itu, kalus yang terbentuk pada penelitian ini potensial untuk dijadikan material dalam proses regenerasi tanaman $B$. bimaensis secara in vitro. 


\section{KESIMPULAN}

Hasil penelitian mengenai induksi kalus pada daun B. bimaensis secara in-vitro dengan perlakuan ZPT 2,4-D dan kinetin diperoleh kesimpulan sebagai berikut : Bagian pangkal daun adalah eksplan yang paling baik dalam induksi kalus. Kecepatan waktu berkalus yang paling cepat adalah pada 20 hari setelah tanam di kombinasi media $\mathrm{D}_{1} \mathrm{~K}_{2}(\mathrm{MS}+1 \mathrm{ppm}$ kinetin). Kombinasi media $D_{1} K_{3}(M S+2 p p m$ kinetin); $\mathrm{D}_{2} \mathrm{~K}_{2}$ (MS + 0.5ppm 2,4-D + 1 ppm kinetin); $\mathrm{D}_{2} \mathrm{~K}_{3}$ (MS + 0.5ppm 2,4-D + 2ppm kinetin) dan $\mathrm{D}_{3} \mathrm{~K}_{2}$ (MS + 1ppm 2,4-D + 1ppm kinetin) memberikan persentase eksplan berkalus paling baik sebesar $100 \%$.

\section{UCAPAN TERIMA KASIH}

Penulis mengucapkan terima kasih kepada Ahmad Muzakki (Mahasiswa Politeknik Negeri Jember) dan Dyah Permatasari Fitrawantio (Mahasiswi Fakultas Pertanian Universitas Brawijaya) yang telah banyak membantu secara teknis dalam penelitian ini. Kepada Arief Priyadi yang telah membantu dan memberikan masukan dalam proses analisis data.

\section{DAFTAR PUSTAKA}

Abumhadi N, Kamenarova K, Todorovska E, Dimov G, Trifonova A, Gecheff K, Atanassov A. 2014. Callus induction and plant regeneration from barley mature embryos (Hordem vulgare L.). Biotechnology and Biotechnological Equipment 19(3): 32-38. DOI: 10.1080/ 13102818.2005.10817224

Aswathy JM, Murugan K. 2017. Comparison of purified anthocyanin isolated from in vitro cell suspension culture of Begonia malabarica, Begonia rex-cultorum 'Baby Rainbow' and its antioxidant activity. International Journal of Pharmacognosy and Phytochemical Research 9(8): 1100-1109. ISSN: 0975-4873. DOI: 10.25258/phyto. v9i08.9617

Awal A. 2009. Tissue culture and morphogenesis of Begonia X hiemalis Fotsch. cv. Schwabenland Red. PhD Dissertation, Faculty Of Science University Of Malaya, Kuala Lumpur.
Awal A, Ahmed ABA, Taha RM, Yaacob JS, Mohajer S. 2013. Effect of adenine, sucrose and plant growth regulators on the indirect organogenesis and on in vitro flowering in Begonia $x$ hiemalis Fotsch. Australian Journal of Crop Science 7(5): 691-698.

Budisantoso I, Amalia N, Kamsinah. 2017. In vitro callus induction from leaf explants of Vanda sp. stimulated by 2,4-D. Biosaintifika 9(3): 492-497. DOI: 10.15294/biosaintifika.v9i3. 11018.

George EF. 2008. Plant tissue culture procedure background. In: George EF, Hall MA, De Klerk GJ (eds) Plant Propagation by Tissue Culture. $3^{\text {rd }}$ Edition. Springer. Dordrecht, The Netherlands.

Gunawan LW. 1995. Teknik kultur in vitro dalam hortikultura. Penebar Swadaya. Jakarta.

Hu WH, Chang C, Peng Cl, Liaw SI. 2010. In vitro flowering and fruiting of Begonia parvula $\mathrm{H}$. Lév. \& Vaniot. European Journal of Horticultural Science 75(4): 172-176.

Hughes M, Moonlight PW, Jara-Muñoz A, Tebbitt MC, Wilson HP, Pullan M. 2015. Begonia Resource Centre. Online database available from http://padme.rbge.org.uk/begonia/. Diakses 4 Maret 2019.

Karimian R, Lahouti M, Davarpanah SJ. 2014. Effects of different concentration of 2,4-D and kinetin on callogenesis of Taxus brevifolia Nutt. Journal of Applied Biotechnology Reports 1(4): 167-170.

Kartikasari P, Hidayat MT, Ratnasari E. 2013. Pengaruh zat pengatur tumbuh 2,4-d (2,4dichlorophenoxyacetic acid) dan kinetin (6furfurylaminopurine) untuk pertumbuhan tunas eksplan pucuk tanaman jabon (Anthocephalus cadamba Miq. ex Roxb.) secara in vitro. Lentera Bio 2(1): 75-80.

Kaviani B, Hashemabadi D, Khodabakhsh H, Onsinejad R, Ansari MH, Haghighat N. 2015. Micropropagation of Begonia rex Putz. by 6benzyladenine and $\alpha$-naphthalene acetic acid. International Journal of Biosciences 6(5): 8-15.

Kumari A, Baskaran $P$, van Staden J. 2017. In vitro regeneration of Begonia homonyma a threatened plant. South African Journal of Botany 109: 174-177 
Kumaria S, Kehie M, Bhowmik SSD, Singh M, Tandon P. 2012. In vitro regeneration of Begonia rubrovenia var. meisneri C.B. Clarke-A rare and endemic ornamental plant of Meghalaya, India. Indian Journal of Biotechnology 11: 300-303.

Ling APK, Tang KY, Gansau JA, Hussein S. 2009. Induction and maintenance of callus from leaf explants of Mirabilis jalapa L. Medicinal and Aromatic Plant Science and Biotechnology 3(1): 42-47.

Machakova I, Zazimalova E, George EF. 2008. Plant growth regulators I: introduction, auxins, their analogues and inhibitors. In: George EF, Hall MA, De Klerk GJ (eds) Plant Propagation by Tissue Culture. $3^{\text {rd }}$ Edition. Springer. Dordrecht, The Netherlands.

Manuela M, Carmen N. 2013. Study on the vegetative propagation of some Begonia $\mathrm{L}$. species. University of Craiova Vol XVIII (LIV): 223-228.

Mei TA, Danial M, Mahmood M, Subramaniam S. 2012. Exquisite protocol of callus induction and protocorm-like bodies (PLBs) regeneration of Dendrobium sonia-28. Australian Journal of Crop Science 6(5): 793800.

Mendi YY, Curuk P, Kocaman E, Unek C, Eldogan S, Gencel G, Cetiner S. 2009. Regeneration of Begonia planlets by direct organogenesis. African Journal of Biotechnology 8(9): 18601863.

Murashige T, Skoog F. 1962. A revised medium for rapid growth and bioassays with tobacco tissue cultures. Plant Physiology 15: 473479.

Nada S, Chennareddy S, Goldman S. 2011. Direct shoot bud differentiation and plantlet regeneration from leaf and petiole explants of Begonia tuberhybrida. Hortscience 46(5): 759-764.

Nhut DT, Hai NT, Phan MX. 2010. A highly efficient protocol for micropropagation of Begonia tuberous. In: Jain SM, Ochatt SJ (eds.). Protocols for In Vitro Propagation of Ornamental Plants, Methods in Molecular Biology, vol. 589. Humana Press. New Jersey.

Niknejad A, Kadir MA, Kadzimin SB. 2011. In vitro plant regeneration from protocorm-like bodies (PLBs) and callus of Phalaenopsis gigantea (Epidendroidea: Orchidaceae). African Journal of Biotechnology 10(56): 11808-11816. DOI: 10.5897/AJB10.2579

Pierik RLM. 1987. In vitro culture of higher plants. Martinus Nijhoff Publisher. London.

Rahayu B, Solichatun E, Anggarwulan. 2003. Pengaruh asam 2,4-diklorofenoksiasetat $(2,4-D)$ terhadap induksi dan pertumbuhan kalus serta kandungan flavonoid kultur kalus Acalypha indica L. Biofarmasi 1(1): 1-6.

Rashid U, Ali S, Ali GM, Ayub N, Masood MS. 2009. Establishment of an efficient callus induction and plnat regeneration system in Pakistani wheat (Triticum aestivum) cultivars. Electronic Journal of Biotechnology 12(3): 112. DOI: $10.2225 /$ vol12-issue3-fulltext-1.

Rowe O, Gallone A. 2016. Investigation into the effect of 6-Benzylaminopurine and 1Naphthaleneacetic acid concentrations on 3 micropropagated Begonia rex 'Fedor' explants. International Forum - Agriculture, Biology and Life Science (IFABL 2016), Kurume, Fukuoka Japan, 5-7 August 2016. Proceedings of the 2016 International Forum-Agriculture, Biology, and Life Science: 131-144.

Rosilah AA, Kandasamy KI, Faridah QZ, Namasivayam P. 2014. Somatic embryogenesis and plant regeneration from leaf explants of endemic Begonia pavonina. Journal of Biology and Earth Sciences 4(2): B113-B119.

Rosyidah M, Evie R, Yuni SR. 2014. induksi kalus daun melati (Jasminum sambac) dengan penambahan berbagai konsentrasi dichlorophenoxyacetic acid (2,4-D) dan 6-benzylamino purin (BAP) pada media MS secara in vitro. Jurnal Biologi 3(3): 147-153.

Rout GR, Mohapatra A, Jain SM. 2006. Tissue culture of ornamental pot plant: a critical review on present scenario and future prospects. Biotechnology Advances 24: 531560.

Sara K, Yousef G, Ghorbanali N, Roghayeh A, Behzad SK, Mohammad Y. 2012. Effect of explant type and growth regulators on in vitro micropropagation of Begonia rex. International Research Journal of Applied Basic Sciences 3(4): 896-901. 
Siregar HM. 2017. The conservation of lowland Indonesian Begonia in Bogor Botanic Gardens. Biodiversitas 18(1): 326-333.

Tahir SM, Victor K, Abdulkadir S. 2011. The effect of 2,4-dichlorophenoxy acetic acid (2,4-D) concentration on callus induction in sugarcane (Saccharum officinarum). Nigerian Journal of Basic and Applied Sciences 19(2): 213-217.

Taiz L, Zeiger E. 2002. Plant Physiology. Third Edition. Sinauer Associates. Sunderland.

Tang, YP, Liu XQ, Gituru RW, Chen LQ. 2010. Callus induction and plant regeneration from in vitro cultured leaves, petiole and scales of Lilium leucanthum (Baker) Baker. Biotechnology and Biotechnological Equipment 24(4): 2071-2076. DOI: 10.2478/ V10133-010-0077-4.

Tian D, Xiao Y, Tong Y, Fu N, Liu Q, Li C. 2018. Diversity and conservation of Chinese wild Begonias. Plant Diversity 40: 75-90.

Tebbit MC. 2005. Begonias: cultivation, identification and natural history. Timber Press Inc. Portland.

Undaharta NKE, Ardaka IM, Kurniawan A, Adjie B. 2015. Begonia bimaensis, a new species of Begonia from Sumbawa Island, Indonesia. Gardens' Bulletin Singapore 67(1): 95-99.

Van Staden J, Zazimalova E, George EF. 2008. Plant growth regulator II. In: George EF, Hall MA, De Klerk GJ (eds) Plant propagation by tissue culture. $3^{\text {rd }}$ edition. Springer. Dordrecht, The Netherlands.

Warseno T, Undaharta NKE, Hendriyani E. 2018. Multiplikasi tunas Begonia salaziensis Warb. sebagai upaya konservasi tumbuhan terancam punah secara in vitro. Buletin Kebun Raya 21(2): 99-108.

Zawawi DA, Jaafar H, Manaf AA. 2013. Effects of 2,4$D$ and kinetin on callus induction of Barringtonia racemosa leaf and endosperm explants in different types of basal media. Asian Journal of Plant Sciences 12: 21-27. 